\title{
Acceptance and Use of Social Media Banking in Sultanate of Oman
}

\author{
Tina Rachel Thomas ${ }^{1}$, Prashant Kumar Singh ${ }^{2}$, Syed Aulia ${ }^{3}$ \\ ${ }^{l}$ MBA Student Waljat College of Applied Sciences Muscat OMAN \\ ${ }^{2}$ Asst.Professor Waljat College of Applied Sciences Muscat OMAN
}

*Corresponding Author: Tina Rachel Thomas, ${ }^{1}$ MBA Student Waljat College of Applied Sciences Muscat OMAN

\begin{abstract}
The emergence of Social Media revolution in this present era has not only transformed customer's routine behavior but has also influenced their demand and expectation patterns from their financial partners resulting in the evolving paradigm shift from traditional banking system to Social Media banking (SMB). The growing popularity of Social Media and their increasing adoption rate by financial institutions in different parts of the world lays the foundation for this study. This study focuses on the acceptance and use of Social Media banking in the Sultanate of Oman, which is witnessing remarkable economic and technological development in the past few years. For this study, the different dimensions of Unified theory of acceptance and use of technology (UTAUT) is assessed and studied with the help of a developed structured undisguised questionnaire comprising scales and is administered among existing users and potential users of Social Media banking in Oman. The data collected was analyzed with the help of analytical tools like SPSS and PLSSEM. It was found that Effort Expectancy (EE) has the highest significant influence on Behavior Intention (BI) towards SMB followed by the significant influence of Behavior Intention(BI) on Usage Behavior(UB) of SMB. Social Media provides an extensive platform for banks to connect to people located at diverse geographic locations, share their information and improve relationship with customers. Thus this study will form a framework for research and development in this sector, which will benefit not only banks and customers, but also other financial institutions
\end{abstract}

Keywords: Social Media, Banking, Behavior, Sultanate of Oman.

\section{INTRODUCTION \& LITERATURE REVIEW}

Social Media Banking (SMB) being one of the budding areas of research study in the present day has gained a favorable proposition of acceptance among the residents in Oman. This chapter mainly highlights the background of study with the help of seven sections viz.; Problem Statement, Theoretical Concepts and Framework, Literature Review, Significance of Study, Objectives of the Study, Hypotheses and Scope of the Study. Problem Statement provides the groundwork of study while the assimilation of extant literature review relevant to the topic of study has led to the development of a conceptual model and suitable hypothesis. Objectives, significance and scope of study present a clear understanding of this research and its implications.

In today's world, there has been a drastic trend shift in customer's needs and expectations, in this rapidly progressing world, where people has prioritized convenience in their life, long gone are the days when people patiently used to visit their local bank branch for most of their transactions. There are many reasons due to which all these strategies in place, social banking system has been influencing larger sections of society with passing time. (Bosheim, 2012)

Social media banking has an essential role in differentiating brands, achieving competitive advantage and making them more relevant to customers besides identifying dissatisfied customers, and increase the impact and reach of traditional media efforts. (Accenture, 2011)

\subsection{Problem Statement}

In this modern era of rapid technological advancement, each and every business sector has to achieve a competitive advantage to strive in the market, which is made possible through market research, innovation, understanding and meeting customer needs and expectations etc. Social Media is one such 
technological platform that has become an essential part of an individual's life in the present day, hence attracting the banking sectors to reach out to customers better, through this platform. The increasing interest and adoption rate of banking sector towards social media, along with the limited research studies undertaken in Oman, in this area is the driving factor behind this research study.

\subsection{Theoretical Concepts and Framework}

Banks have been adopting migration strategy to shift their clients from traditional ways to automated services, branches encourage them to use ATMs, POS, Internet and mobile technology which require less resource and incur comparatively less operational costs. In the present world, mobile devices have become consumer's popular tools that are used for banking, payments, budgeting and shopping. (Farshid, M., Plangger 2011) In brief, Social Media banking is the process of engaging banking customers with the aim of increasing customer intimacy, better customer relationship management and to leverage influencers through Social Media platform. The acceptance and use of Social Media banking among the public, is measured through the scale of UTAUT which has the following dimensions: Performance expectancy, Behavioral intention, Social influence, Effort expectancy and Facilitating conditions.( Deloitte. 2013)

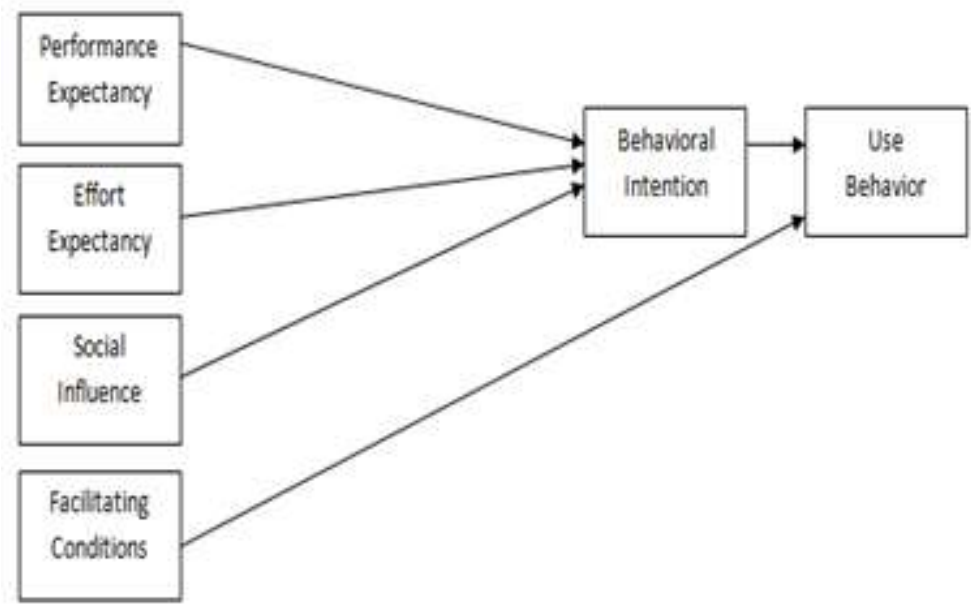

Figure1. Conceptual Framework based on UTAUT

\subsection{UTAUT Model}

UTAUT model, the most prevalent model used by researchers to study the users' adoption to technology (Sareen \& Jain, 2014) is based on eight technology acceptance theories or models viz.; the Theory of Reasoned Action (TRA), the Technology Acceptance Model (TAM), the Motivational Model, the Theory of Planned Behaviour (TPB), the combined TAM and TPB, the model of Personal Computer Utilization, the Innovation Diffusion Theory and the Social Cognitive Theory. (Venkatesh et al, 2003). Taking into consideration the relevance of the model, acceptance and use of Social Media banking among the public, is measured through the scale of UTAUT.

\subsection{Significance of Study}

This research proves significant to the following sections of society, banks with the help of this study, banks in Oman can acquire a clear understanding of the customer's Social Media banking acceptance and usage rate in the region. They can get a clear insight about the existing and potential customers lurking in Oman. Financial Institutions: Along with banks, other financial institutions in the region can also get their required source of information from this research study. This study provides groundwork for other financial institutions to adopt Social Media in their business activity to connect to the public.

\subsection{Objectives of the Study}

To examine the effect of Performance expectancy of SMB on Behavioural Intention to use SMB. To examine the relationship between Effort expectancy and Behavioral Intention to use SMB. To examine the relationship between Social Influence and Behavioral Intention to use SMB. To examine the effect of facilitating conditions on Use Behavior of SMB.

To examine the effect of Behavioral Intention to use SMB on Use Behavior of SMB. 


\subsection{Scope of the Study}

Initially this study focuses on a definite sample size selected through convenient sampling design from select regions in Oman. Each of the dimensions can be further studied on a wider scale through a broader sample size to obtain more accurate and precise results required by the researcher. Also there are many extension factors of UTAUT model which can help in making different types of analysis.

\section{RESEARCH METHODOLOGY}

\subsection{Research Design}

This research study is undertaken using a quantitative technique of research, to examine the acceptance and use of Social Media banking in the Sultanate of Oman. A structured undisguised questionnaire based on UTAUT scale was administered among the residents of Oman, who either has the knowledge or experience with Social Media banking.

\subsection{Sampling Design}

This research study was administered through a self reported questionnaire, based on UTAUT scale, on a definite sample comprising of people who have the knowledge or experience with Social Media banking, using convenience sampling technique. This technique was adapted due to time constraints, cost effectiveness and due to its relatively easier process.

\subsection{Data Collection Method(s)}

A structured, self-reported and undisguised questionnaire adopted and adapted from a standardized scale of UTAUT was administered among suitable respondents in the form of online questionnaires and in person.

\subsection{Analysis of Data: Tools \& Techniques}

The data collected from the sample respondents was fed into analytical tool packages like SPSS and PLS-SEM for further statistical analysis. While SPSS helped in acquiring descriptive statistics of the demographic variables, PLS-SEM was used to perform path analysis with the help of Structural Equation Modelling. Through PLS-SEM, the proposed model was tested along with obtaining the cronbach alpha, composite reliability, $\mathrm{AVE}$ and $\mathrm{R}^{2}$ of the constructs.

\subsection{Limitations to the Study}

Only articles in English language available through online databases were reviewed and retrieved.

Only major factors of the UTAUT model relevant to this study were adopted in the research framework.

The moderating variables of UTAUT model were not included in the research framework.

\subsection{Results \& Discussion}

The data collected from three categories of respondents (sample size $=110$ ) that included active users, latent users and non-users who might be prospective users of SMB was subsequently keyed into SPSS and PLS-SEM for further statistical analysis.

\subsection{Findings of the Study}

Table1. Statistics - Mean

\begin{tabular}{|l|l|r|r|r|r|r|r|}
\hline \multicolumn{2}{|c|}{} & \multicolumn{1}{|c|}{ Gender } & \multicolumn{1}{|c|}{ Age } & Nationality & Experience & Education Level & Occupation \\
\hline \multirow{2}{*}{$\mathrm{N}$} & Valid & 110 & 110 & 110 & 110 & 110 & 110 \\
\cline { 2 - 8 } & Missing & 0 & 0 & 0 & 0 & 0 & 0 \\
\hline Mean & 1.57 & 1.72 & 1.83 & 1.93 & 4.82 & 2.52 \\
\hline
\end{tabular}

Table2. Frequency distribution - Gender

\begin{tabular}{|l|l|r|r|r|r|}
\hline \multicolumn{2}{|c|}{} & Frequency & Percent & Valid Percent & \multicolumn{1}{c|}{ Cumulative Percent } \\
\hline \multirow{3}{*}{ Valid } & male & 47 & 42.7 & 42.7 & 42.7 \\
\cline { 2 - 6 } & female & 63 & 57.3 & 57.3 & 100.0 \\
\cline { 2 - 6 } & Total & 110 & 100.0 & 100.0 & \\
\hline
\end{tabular}

Majority of respondents in the research survey are females (57.3\%). 
Acceptance and Use of Social Media Banking in Sultanate of Oman

Table3. Frequency distribution - Nationality

\begin{tabular}{|l|l|r|r|r|r|}
\hline \multicolumn{2}{|c|}{} & Frequency & Percent & Valid Percent & Cumulative Percent \\
\hline \multirow{3}{*}{ Valid } & omani & 19 & 17.3 & 17.3 & 17.3 \\
\cline { 2 - 6 } & non omani & 91 & 82.7 & 82.7 & 100.0 \\
\cline { 2 - 6 } & Total & 110 & 100.0 & 100.0 & \\
\hline
\end{tabular}

Majority of respondents in the research survey are Non-Omanis (82.7\%).

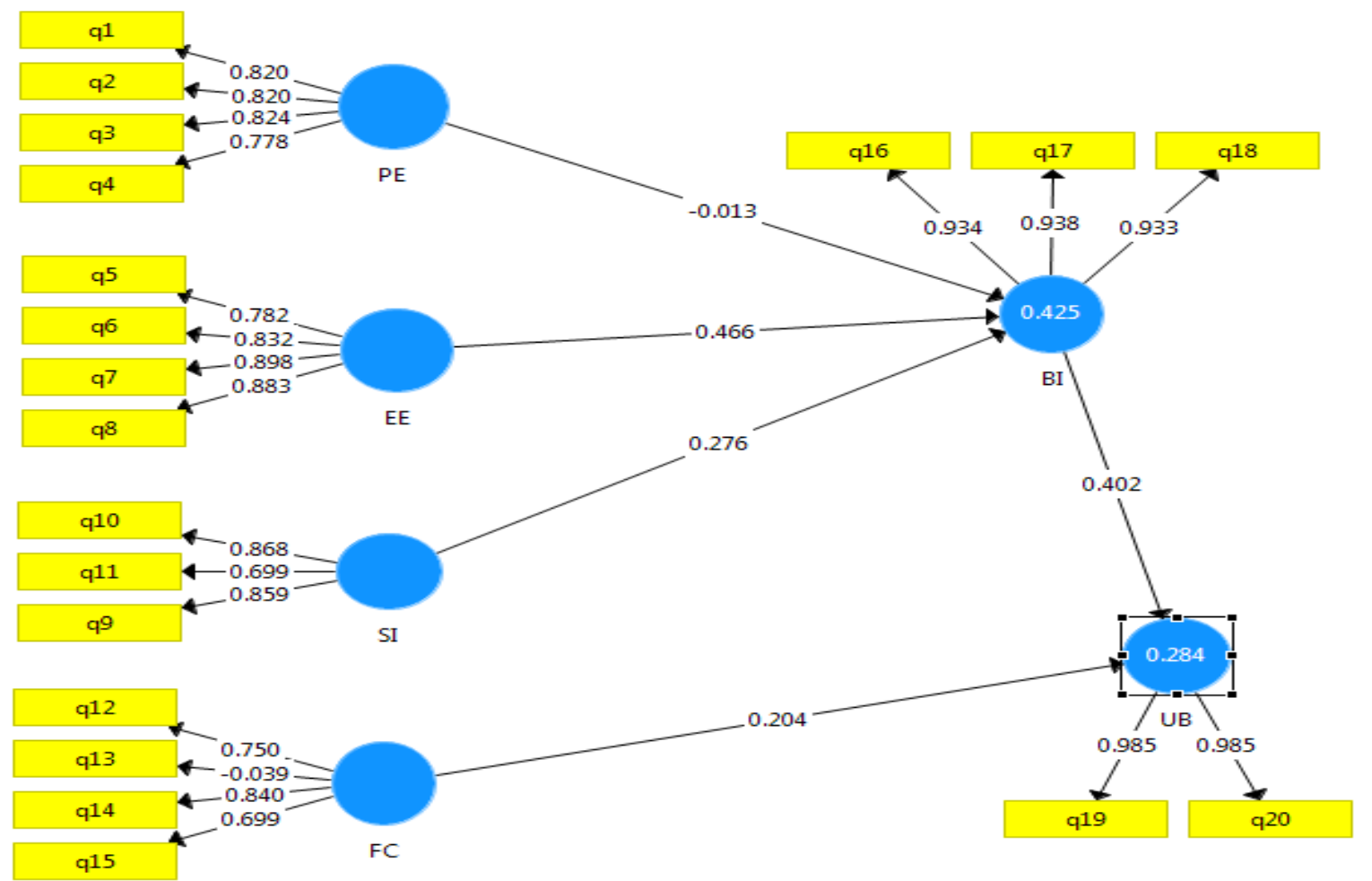

Fig2. PLS results for proposed Research Model

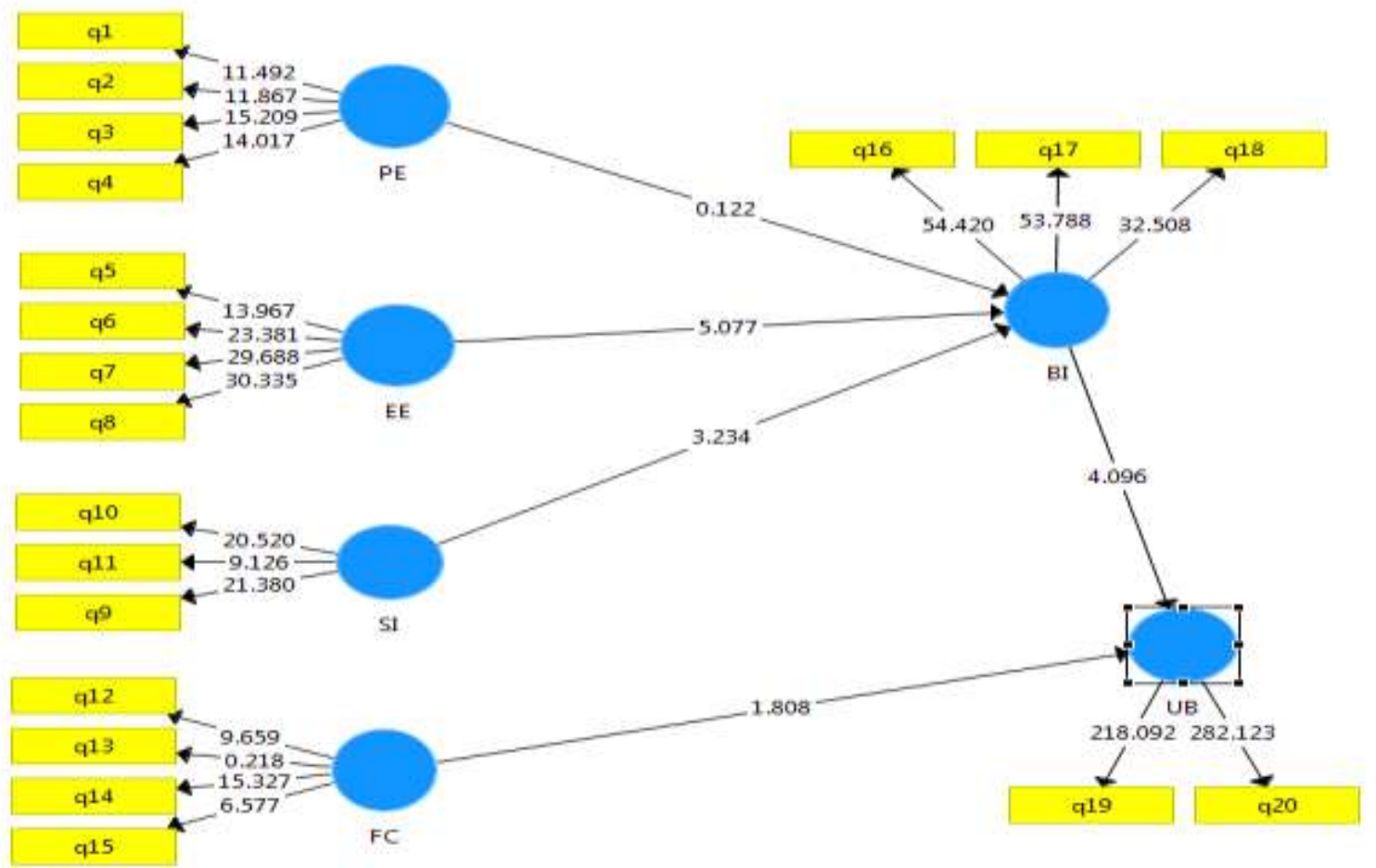

Fig3. PLS results for proposed Research Model after bootstrapping 
Table4. Results summary for PLS model (Refer fig. 2).

\begin{tabular}{|c|c|c|c|c|c|}
\hline Latent Variable & Indicators & Loadings & $\begin{array}{c}\text { Average } \\
\text { Variance } \\
\text { Extracted } \\
(\text { AVE) }\end{array}$ & $\begin{array}{l}\text { Composite } \\
\text { Reliability }\end{array}$ & $\begin{array}{c}\text { Cronbach } \\
\text { Alpha }\end{array}$ \\
\hline \multirow{4}{*}{$\begin{array}{l}\text { Performance } \\
\text { Expectancy (PE) }\end{array}$} & 1 & 0.820 & \multirow{4}{*}{0.657} & \multirow{4}{*}{0.885} & \multirow{4}{*}{0.827} \\
\hline & 2 & 0.820 & & & \\
\hline & 3 & 0.824 & & & \\
\hline & 4 & 0.778 & & & \\
\hline \multirow{4}{*}{$\begin{array}{l}\text { Effort Expectancy } \\
\text { (EE) }\end{array}$} & 5 & 0.782 & \multirow{4}{*}{0.722} & \multirow{4}{*}{0.912} & \multirow{4}{*}{0.871} \\
\hline & 6 & 0.832 & & & \\
\hline & 7 & 0.898 & & & \\
\hline & 8 & 0.883 & & & \\
\hline \multirow{3}{*}{$\begin{array}{l}\text { Social Influence } \\
\text { (SI) }\end{array}$} & 9 & 0.868 & \multirow{3}{*}{0.660} & \multirow{3}{*}{0.852} & \multirow{3}{*}{0.736} \\
\hline & 10 & 0.699 & & & \\
\hline & 11 & 0.859 & & & \\
\hline \multirow{4}{*}{$\begin{array}{l}\text { Facilitating } \\
\text { Conditions (FC) }\end{array}$} & 12 & 0.750 & \multirow{4}{*}{0.440} & \multirow{4}{*}{0.693} & \multirow{4}{*}{0.497} \\
\hline & 13 & -0.039 & & & \\
\hline & 14 & 0.840 & & & \\
\hline & 15 & 0.699 & & & \\
\hline \multirow{3}{*}{$\begin{array}{l}\text { Behavioral Intention } \\
\text { to use SMB (BI) }\end{array}$} & 16 & 0.934 & \multirow{3}{*}{0.874} & \multirow{3}{*}{0.954} & \multirow{3}{*}{0.928} \\
\hline & 17 & 0.938 & & & \\
\hline & 18 & 0.933 & & & \\
\hline \multirow[t]{2}{*}{ Use Behavior (UB) } & 19 & 0.985 & \multirow{2}{*}{0.971} & \multirow{2}{*}{0.985} & \multirow{2}{*}{0.970} \\
\hline & 20 & 0.985 & & & \\
\hline
\end{tabular}

Composite reliability is an indicator of internal consistency and the value should be higher than 0.70 . Table 8 indicates that the values of composite reliability for all latent variables except Facilitating Conditions are more than 0.70. The Cronbach alpha for Facilitating Conditions is also quite low (0.497).

The R Square value for: $\mathrm{BI}-0.425$ and UI -0.284

Effort Expectancy has the strongest effect on Behavioral Intention to use SMB (0.466) followed by Behavioral Intention to use SMB on Use Behavior (0.402).

In order to test the significance of the standardized regression weights for effects obtained using PLS and depicted in PLS (refer Fig. 2), bootstrapping was carried out. The t-statistics values obtained after bootstrapping (subsamples $=5000$ ) were examined as an indicator of significance of standardized regression weights obtained in PLS results. The bootstrapping results (refer Fig. 3) revealed that Effort Expectancy had the strongest effect on Behavioral Intention to use SMB (t statistic=5.077), followed by the effect of Behavioral Intention to use SMB on Use Behavior ( $t$ statistic $=4.096)$ and the effect of Social Influence on Behavioral Intention to use SMB (t statistic=3.234).

Table5. Path coefficients (refer fig 2)

\begin{tabular}{|c|c|c|c|c|c|}
\hline & $\begin{array}{c}\text { Original } \\
\text { Sample (O) }\end{array}$ & $\begin{array}{c}\text { Sample Mean } \\
(\mathbf{M})\end{array}$ & $\begin{array}{c}\text { Standard } \\
\text { Error } \\
(\text { STERR })\end{array}$ & $\begin{array}{c}\text { T Statistics } \\
(\mid \mathbf{O} / \text { STERR })\end{array}$ & P Values \\
\hline BI -> UB & 0.402 & 0.391 & 0.098 & 4.096 & 0.000 \\
\hline EE -> BI & 0.466 & 0.458 & 0.092 & 5.077 & 0.000 \\
\hline FC -> UB & 0.204 & 0.226 & 0.113 & 1.808 & 0.071 \\
\hline PE -> BI & -0.013 & 0.005 & 0.103 & 0.122 & 0.903 \\
\hline SI -> BI & 0.276 & 0.276 & 0.085 & 3.234 & 0.001 \\
\hline
\end{tabular}

\subsection{Discussion on findings of the study}

From the frequency distribution tables represented above of all the demographic variables used in this research study, it clearly reveals the following information:

- Majority of respondents who participated in the research survey were females (57.3\%).

- Majority of respondents who participated in the research survey belong to the age group 21-30 (62.7\%). 
- Majority of respondents who participated in the research survey were non-domains (82.7\%).

- Majority of respondents who participated in the research survey have some experience in SMB $(56.4 \%)$.

- Majority of respondents who participated in the research survey were pursuing education at Bachelors level (59.1\%).

- Majority of respondents who participated in the research survey were students (72.7\%).

- Based on the results obtained through PLS-SEM, three hypotheses, have been supported at $95 \%$ confidence level (t statistic > 1.96, refer Fig. 8), whereas two hypotheses couldn't be supported. The significant relationships obtained as a result of this study are as follows:

- EE-> BI

- $\mathbf{B I}->\mathrm{UB}$

- $\mathrm{SI}$-> BI

\section{CONCLUSIONS}

The data collected from three categories of respondents (sample size $=110)$ that included active users, latent users and non-users who might be prospective users of SMB was analyzed using analytical tools and inferences were made. The proposed research model comprises of four constructs viz.; Performance Expectancy, Effort Expectancy, Social Influence and Facilitating Conditions, in which it has been observed that Effort Expectancy and Social Influence has made significant contribution on Behavior Intention to use SMB. Furthermore, Behavior Intention has been found to make significant contribution on Use Behavior of SMB.

However, the data collected could not capture the significant relationship between Performance Expectancy and Behavior Intention towards SMB. In addition to that, the significant relationship between Facilitating Conditions and Use Behavior of SMB was also not supported by the data.These observations and findings from our convenience sampling data offer an insight into the developing field of SMB.

\section{SugGeSTIONS}

Banking and Technology have been popular research interests owing to the significant importance it has on society at large. The following suggestions can prove beneficial for researchers working on similar projects:

- This research study focuses on few factors that can influence behavioral intention to use SMB and the actual use behavior with SMB, but there are many more factors that can contribute to behavior intention and use behavior, which can lead to extensive and in depth research.

- Though demographic variables were not studied in this research, their impact on the proposed model can make this study more practical and functional.

\section{DireCTIONS FOR FUTURE RESEARCH}

According to (Accenture, 2012) the Next Generation Banking models comprises of banking models coming to realization in the forthcoming years, has paved way for extensive research and development in this area. Among these models, Social Media Banking though in its nascent stage in Oman, has found to be a relevant and emerging platform. Hence SMB has widespread research potential in different dimensions like:

- Psychographic factors and its influence on Intention and Usage behavior of SMB

- Customer Engagement and SMB

- Customer Relationship Management and SMB

\section{REFERENCES}

[1] Accenture. (2011). Social Banking: The Social Networking Imperative for Retail Banks. Social banking: The Social Networking Imperative for Retail Banking. Retrieved from http://www.accenture.com/ SiteCollectionDocuments/PDF/Accenture-Social-Banking-Retail.pdf 
[2] Accenture. (2012). Banking 2016 Accelerating growth and optimizing costs in distribution and marketing (Vol. Accenture). Retrieved from http://www.accenture.com/SiteCollectionDocuments/PDF/Financial Services/Accenture-Banking-2016.pdf

[3] Bosheim, S. A. (2012). Social banks and impact measurement: The cases of Charity Bank and Triodos Bank. Retrieved from http://www.social-banking.org/fileadmin/isb/Artikel_und_Studien/Paper_Series/ Paper_No.10.pdf

[4] Deloitte. (2013). Who says banks can't be social? Become a social bank, inside and out. Retrieved from https://www2.deloitte.com/content/dam/Deloitte/global/Documents/Financial-Services/gx-fsi-ca-whosaid-bank-cant-be-social-2013-10.pdf

[5] Farshid, M., Plangger, K., \& Nel, D. (2011). The social media faces of major global financial service brands. Journal of Financial Services Marketing, 16(3-4), 220-229. doi:10.1057/fsm.2011.19

[6] Sareen, M., \& Jain, A. (2014). THE ROLE OF SOCIAL INFLUENCE AND CONSUMER' S EFFORT EXPECTANCY ON ONLINE SHOPPING : AN EMPIRICAL STUDY OF INDIA, 3(2319-345X), 158 Retrieved from http://www.ijmrbs.com/ijmrbsadmin/upload/IJMRBS_52dc157d2dce3.pdf

[7] Venkatesh, V., Morris, M. G., Davis, G. B., \& Davis, F. D. (2003). User acceptance of information technology: Toward a unified view. MIS Quarterly, 27(3), 425-478. doi:10.2307/30036540

Citation: Tina Rachel, Thomas et al. "Acceptance and Use of Social Media Banking in Sultanate of Oman." International Journal of Managerial Studies and Research (IJMSR), vol 5, no. 11, 2017, pp. 90-96. doi:http://dx.doi.org/10.20431/2349-0349.0511010.

Copyright: () 2017 Authors. This is an open-access article distributed under the terms of the Creative Commons Attribution License, which permits unrestricted use, distribution, and reproduction in any medium, provided the original author and source are credited. 